Raquel Carrasco $\cdot$ Juan F. Jimeno $\cdot$ A. Carolina Ortega

\title{
The effect of immigration on the labor market performance of native-born workers: some evidence for Spain
}

\begin{abstract}
This paper provides an approximation to the labor market effects of immigrants in Spain, a country where labor market institutions and immigration policy exhibit some peculiarities, during the second half of the 1990s, the period in which immigration flows accelerated. By using alternative data sets, we estimate both the impact of legal and total immigration flows on the employment rates and wages of native workers, accounting for the possible occupational and geographical mobility of immigrants and native-born workers. Using different samples and estimation procedures, we have not found a significant negative effect of immigration on either the employment rates or wages of native workers.
\end{abstract}

Keywords Immigration - Employment rates - Wages

JEL Classification J21 · J11

R. Carrasco $(\bowtie)$

Department of Economics, Universidad Carlos III, Madrid 126, 28903 Getafe, Madrid, Spain

Fax: +34 91 6249875, E mail: rcarras@eco.uc3m.es

J. F. Jimeno

Research Department, Banco de España, Alcalá 48, 28001 Madrid, Spain

A. C. Ortega

FEDEA, Jorge Juan 46, 28001 Madrid, Spain

J. F. Jimeno

CEPR, London, UK

J. F. Jimeno

IZA, Bonn, Germany

E mail: juan.jimeno@bde.es

A. C. Ortega

Universidad de Alcalá, Alcalá de Henares, Spain

E mail: cortega@fedea.es 


\section{Introduction}

The literature that seeks to evaluate the impact of immigration on the labor market of a host country is by now very large and well surveyed. ${ }^{1}$ Two main conclusions can be drawn from this literature. (1) It has proven very difficult to find support for the implications of the standard textbook model in which an increase in labor supply due to immigration ought to reduce the wages of native workers in flexible labor markets, in which relative wages adjust to demand and supply factors, or to reduce their employment rates in labor markets where rigidities prevent adjustments of relative wages; and (2) empirical results seem to be time- and country-dependent, with a variety of studies finding different estimates of the labor market impact of immigration depending on the episode under consideration.

Most of the empirical studies in this strand of the literature use the so-called "area-analysis" approach, which correlates, across local labor markets, wages and employment rates on one hand, and the incidence of immigration on the other hand. These spatial correlations suggest that, at most, a $10 \%$ increase in the fraction of immigrants reduces the wages of native workers by about $1 \%$.

However, as long as production factors, either capital or labor, are mobile across local labor markets, spatial correlations will fail to capture the degree of substitution between immigrants and native-born workers (see Borjas 1999). Native workers may move from those cities affected by the labor supply shock to other localities unaffected by the immigration influx, firms may want to move into those cities where wages have fallen, and immigrants conceivably select the region of residence depending on employment opportunities. ${ }^{2}$ To control for mobility, a number of studies have focused on the analysis of "natural experiments", where the increase in immigration can be considered as exogenously determined. This is the case of Card (1990) on the Mariel boatlift from Cuba to Miami or Hunt (1992) on the repatriation from Algeria to France. However, they still get no significant effects of immigration on the labor market outcomes of native workers.

In a recent influential paper, Borjas (2003) advocated an alternative approach focusing on correlations across skill groups (using education and labor market experience as indicators of skills), on the grounds that these are categories from which, in the short run, it is impossible for workers to move away, and therefore the degree of substitution between natives and immigrants is bound to be much better gauged. Using this approach, Borjas (2003) found that an increase in the size of a skill group by $10 \%$ lowers the wage of workers in that group by about 2 to $3 \%$ and reduces the working weeks by $2 \%$.

These results, as it is the case for the bulk of the empirical work on the labor market effects of immigration, refer to the USA. ${ }^{3}$ Wealth of data sets and the long experience with the effects of large waves of immigration since the 1840s justify

\footnotetext{
${ }^{1}$ See, for instance, Borjas (1994, 1999) and Friedberg and Hunt (1995).

${ }^{2}$ Nonetheless, Card (2001) and Card and DiNardo (2001) find that in the US cities that have received flows of relatively unskilled immigrants, the relative size of their unskilled populations has also increased, which somewhat challenges the view that the lack of spatial correlations between immigrant flows and local labor market outcomes is due to the mobility of native workers.

${ }^{3}$ However, there are some studies that apply the "spatial correlations" approach to other host countries such as Hunt (1992) to France, Pischke and Velling (1997) to Germany and Dolado et al. (1997) to Spain.
} 
this focus of attention on the USA. However, during the last decade, many European countries have become recipients of immigrants. ${ }^{4}$ Thus, the demand for an informed analysis of the impact of immigration into Europe has notably increased. Moreover, Angrist and Kugler (2003), using a panel of European countries, found that immigration slightly reduced the employment rate of nativeborn workers, although this effect is larger in countries with "rigid" institutions, particularly in countries where product market competition is restricted. This finding suggests that the link between immigration and labor market outcomes of native-born workers may be more subtle than just the insight provided by the static labor demand/labor supply model of the labor market, and that it could vary across countries. $^{5}$

These premises lead us to the main motivation of this paper. Spain is one of the European countries where immigration flows during the last decade have increased noticeably. As seen in Fig. 1a and b, during the second half of the 1990s, the net immigration rate to Spain has reached values close to $1.5 \%$ of the population, and immigration accounts for more than $90 \%$ of the total population growth. Moreover, the Spanish labor market institutions and the immigration policy exhibit some peculiarities, which may be relevant when analysing the impact of immigration. Hence, Spain seems an interesting case of study of the labor market effects of an immigration boom.

There are very few empirical studies trying to measure the impact of immigration on the labor market performance of Spanish workers, most of the research of immigration to Spain being of sociological/qualitative nature (see, for instance, Carrasco 2002 and Izquierdo 2002). Within the economic literature, there are some previous studies. Dolado et al. (1997) analysed the effects of an amnesty of illegal immigrants on the wages and unemployment rates of native-born workers in the late 1980s/early 1990s, whereas Dolado (2002) surveyed the available literature related to the design of migration policies to shed light on the Spanish case. Collado et al. (2004) performed a generational accounting exercise to measure the impact of immigration on public budgets, and Amuedo-Dorantes and De la Rica (2005) explored whether immigrants are more responsive than natives to regional labor market opportunities.

In this paper, we provide an approximation to the labor market effects of immigrants in Spain during the second half of the 1990s, the period in which immigration flows to Spain have accelerated, as briefly documented in Section 2. For this analysis, we rely on the data from the last two waves of the Census of Population for the years 1991 and 2001, the register of work permits to foreigners for the period 1993-1999 and from the last available wave of the Wage Structure Survey (Encuesta de Estructura Salarial) for the year 2002. The information contained in these data sets is described in Section 3. Using it, we estimate both the impact of legal and total immigration flows on the employment rates and wages of

\footnotetext{
${ }^{4}$ For recent immigration trends in some European countries, see Coppel et al. (2001) and Boeri et al. (2002).

${ }^{5}$ The labor market impact of immigration also depends on the technological complementarities between capital and labor of each type in the production function, how wages are determined and what kind of labor market frictions is considered. For a discussion of these issues, see Carrasco et al. (2004).
} 

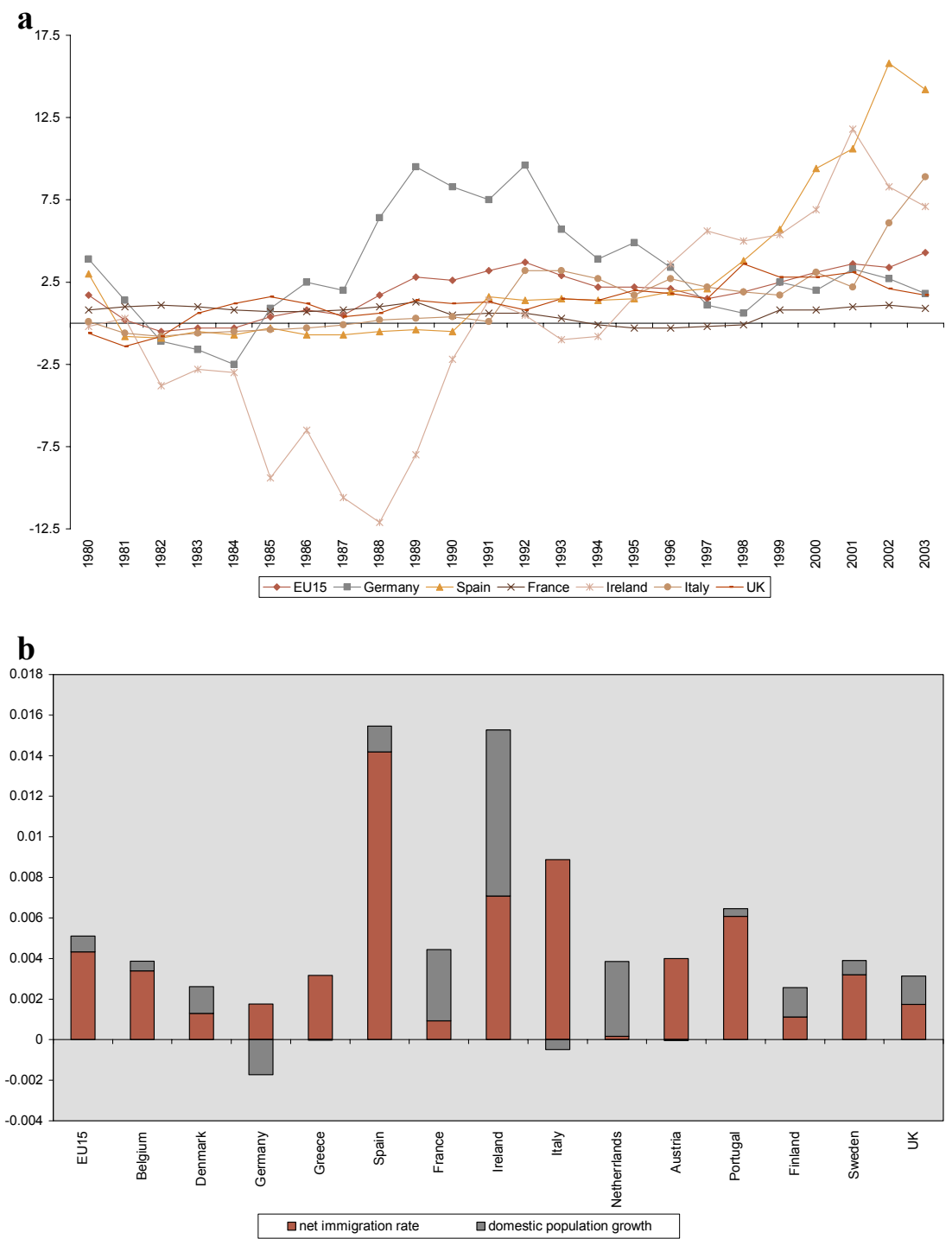

Fig. 1 a Net immigration to several EU countries (per thousands of inhabitants); b population growth and its components in EU15 countries in 2003. Source: Eurostat (NewCronos database)

native workers, accounting for the possible occupational and geographical mobility of immigrants and native-born workers. ${ }^{6}$ The empirical approach and the results are discussed in Sections 4 and 5. Concluding remarks are presented in Section 6.

${ }^{6} \mathrm{~A}$ recent paper with a similar approach to ours is Cohen Goldner and Paserman (2004), who study the Israeli case. 


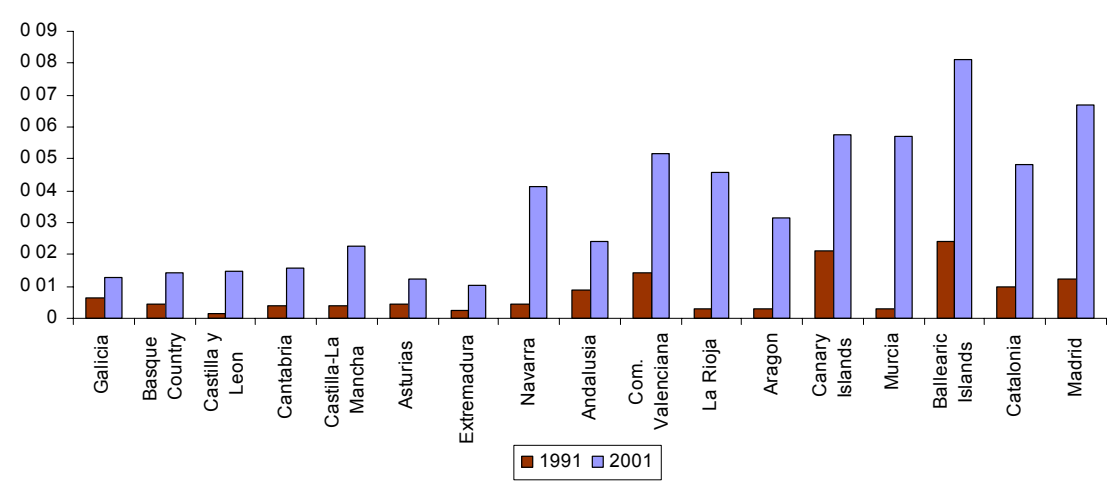

Fig. 2 Foreign population as a proportion of total population by region. Source: Census of Population, 1991 and 2001

\section{Immigration to Spain: a summary of the main trends}

During the last decade, the foreign population in Spain has surged from 0.35 million in 1991 to almost 3.69 million in 2005 , that is, from about 1 to $8.4 \%$ of the total population. ${ }^{7}$ As seen in Fig. 2, census data show a clear regional concentration of immigrants in Madrid and the eastern part of Spain. South America and Africa are the main areas of origin of the immigrants (with weights of about 30 and $20 \%$, respectively). About $50 \%$ of the immigrants have secondary studies, whereas around $15 \%$ have tertiary studies, and almost $60 \%$ of them arrived after 1995 . Finally, immigrants are relatively young, with about $60 \%$ of them in the $20-44$ age group, and men of 25-34 years of age being overrepresented.

Immigrants are required to obtain a work permit if they intend to be either employed or self-employed. Since 1992, European Union (EU) citizens are exempted from this requirement (citizens from Luxembourg since 1993, citizens from Austria, Finland, Norway and Sweden since 1994). Regarding the process that leads to awarding work permits, in the case of an initial authorization, the employers that intend to employ immigrants should request the work permit. Among other documents, the employers have to prove that they had posted a job offer in the Public Employment Services, and that the vacancy has not been filled. In the case of renewals or self-employees, the immigrant workers should request the authorization. Finally, the government authorities decide whether to grant the work permit or not. There are several types of work permits with different duration and restrictions regarding the sectoral and geographical scopes where the immigrant is allowed to work.

By comparison between the census data and the register data, it can be concluded that about one third of the immigrants are in an "irregular situation", that is, without a residence or a work permit. According to estimates from the Spanish

\footnotetext{
${ }^{7}$ Available data sources (Census of Population, Labor Force Survey, administrative registers of residence and work permits, etc.) do not always coincide in the measurement of the stock of foreign population in Spain. This, together with methodological problems caused by changing regulations, somehow blurs the exact incidence and the sectoral and regional distribution of immigrants to Spain.
} 


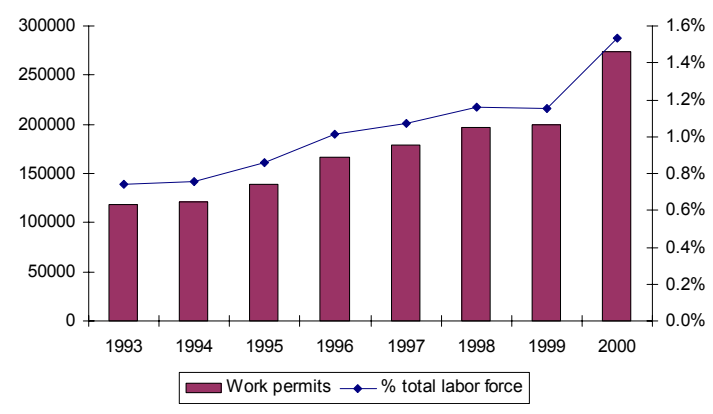

Fig. 3 Work permits (stock). Source: Ministry of Employment and Social Affairs

Ministry of Employment, shown in Fig. 3, the number of work permits has increased from around $120,000(0.7 \%$ of the labor force $)$ in 1993 to around 270,000 ( $1.5 \%$ of the labor force) in $2000 .^{8}$ The large increase in this last year was caused by a special amnesty process, which took place over 2000 and 2001. Most work permits are awarded to immigrants in the service sectors. Immigrants with work permits are also geographically concentrated in some regions, representing a high proportion of the labor force in Madrid, Catalonia, Balearic Islands and Murcia.

\section{Data}

For the estimation of the labor market effects of immigration in Spain, we use four different data sources. Firstly, we obtain measures of the size of the immigrant population and its composition by some personal characteristics, as well as the employment rates of native workers from the last two waves of the Census of Population (1991 and 2001). Immigrants are defined as those individuals with a foreign nationality. ${ }^{9}$ Secondly, we use detailed data on the work permits for the period 1993-1999 from the register of the Spanish Ministry of Employment and Social Affairs to better measure the incidence of legal immigrants participating in the labor market. In this case, the employment rates of native individuals are obtained from the Labor Force Survey. Finally, we use the last available wave of the Wage Structure Survey (2002) to obtain measures of the size and characteristics

\footnotetext{
${ }^{8}$ More recent data for 20002002 have not yet been made available by the Spanish Ministry of Employment. In 2000 2001, there was a special amnesty procedure, and in 2002, new immigration laws were approved after intense political discussions, which seem to be the reasons for the delay in the publication of these data.

${ }^{9}$ We exclude Spanish citizens born abroad from our definition of immigrants as information on duration of residence is only available for foreign born non Spanish citizens, and we control for this variable in some of the regressions. According to the data from the Yearbooks of Statistics on Immigration, only a small fraction of immigrants acquired the Spanish citizenship each year. For example, in 2004, out of a total of 1,977,291 immigrants with a residence permit, only $2 \%$ acquired the Spanish citizenship by reason of residence. In particular, 21,549 immigrants acquired the Spanish citizenship after 2 years of residence, and 7,305 did it after 10 years of residence.
} 
of legal immigrants and wages of native workers..$^{10}$ In what follows, we describe the construction of the variables to be used in our empirical analysis.

Our analysis relies on the correlation between the stock of immigrants and some local labor-market outcomes for native workers across several segments of the labor market. Ideally, these segments should be defined along dimensions across which immigrants and native workers could not relocate themselves, as stressed by Borjas (2003) who uses education and labor market experience. In our case, the definition of segments is determined by data availability. Thus, from the Census of Population and from the Wage Structure Survey, we can observe gender, education and potential labor market experience of immigrants, whereas from the register of work permits, we can only observe their age, gender and the sector where they work. Given these restrictions, we construct three different samples:

Sample I: From the census data, we construct, for years 1991 and 2001, 64 different labor market segments defined by (1) educational level (without studies, primary, secondary and tertiary education), (2) gender and (3) potential work experience (in groupings of 5 years from 0 to 40 ).

Sample II: From the work permits data, we construct, for each year between 1993 and 1999, 352 different labor market segments defined by (1) gender, (2) age groups $(20-34,35-44,45-54,55-65)$ and (3) sectors of activity (44 sectors). ${ }^{11}$

Sample III: From the Wage Structure Survey data, we construct, for 2002, 64 different labor market segments defined by (1) educational level (without studies, primary, secondary and tertiary education), (2) gender and (3) potential work experience (in groupings of 5 years from 0 to 40$)$.

There are two reasons to expect the impact of immigration to be different across genders. First, the substitutability and complementarity relationships between immigrants and native workers might be different for men and women (for example, child-care services provided by immigrant women might have allowed some native women to participate in the labor force). Hence, we expect immigrant men more to be substitutes of native men than immigrant women are of native women. Second, occupational segregation by gender is high in Spain as in many

\footnotetext{
${ }^{10} \mathrm{As}$ EU citizens are not required to have a work permit, they are not counted as immigrants when using this data set. They are included in the stock of immigrants when using data from the Census of Population and the Wage Structure Survey. However, our results are robust to the inclusion or exclusion of EU foreign citizens as immigrants.

${ }^{11}$ The sectors are: agriculture, cattle raising and hunting; fishing; coal mining; oil and gas extraction; extraction of minerals (non energy); food, beverages and tobacco; apparel and textiles; leather products; wood and cork products; paper and printing; refineries; chemical products; rubber and plastics; fabricated non metallic minerals; metal manufacturing; fabricated metal products (excluding machinery); mechanical equipment; office equipment; electrical equipment; precision instruments; automobiles; other transportation equipment; furniture and other manufacturing; production and distribution of electric energy, water and gas; construction; vehicles; sales and repair; wholesale trade; retail trade; hotels and restaurants; transports; sea transports; air transports; other transports and communications; financial activities; real estate; research and development; other entrepreneurship activities; public administration; education; health and social services; public sewerage; cultural and leisure activities; personal services; domestic care.
} 
other countries, and immigrants are also selected into occupations by gender. This also limits the degree of substitutability across natives and immigrants of different gender. An additional more pragmatic reason to include gender in the skill groups' definitions is to duplicate the number of observations for our regression analysis.

Moreover, in some cases, we also add the regional dimension to the construction of labor market segments. We report the results for two alternative specifications, with or without regional variation.

In the three samples, the immigration variable, $x$, is defined as

$$
x_{i t}=\frac{m_{i t}}{\left(n_{i t}+m_{i t}\right)},
$$

where $m$ and $n$ stand for the number of immigrants and the number of native employed workers, respectively, and the subscripts $i$ and $t$ refer to a particular labor market segment and year, respectively.

To capture the labor market outcomes of native workers, we compute, for each cell, the following variables: (1) the employment rate of native workers, $e_{i t}=\frac{n_{i t}}{p_{i t}}$, where $p$ stands for the native population, ${ }^{12}$ and (2) the mean annual and hourly wages of native workers, $\mathrm{aw}_{i t}$ and $\mathrm{hw}_{i t}$, respectively.

Summary statistics of the variables included in the three samples are presented in Table 1. In the sample from the Census of Population, the stock of immigrants, $x$, takes an average value of $5.67 \%$, ranging from $0.30 \%$ (men with no formal studies and 36 to 40 years of work experience in 1991) to $38.27 \%$ (men without studies and 11 to 15 years of work experience in 2001). The mean of the employment rate is about $58.64 \%$. In the sample of work permits, the immigration rate, $x$, is around $0.89 \%$. The average value of the employment rate as it was constructed is around $1.2 \%$. If we add $e_{i t}$ across sectors, we obtain an average value of the employment rate of $51.96 \%{ }^{13}$ Finally, in the sample from the Wage Structure Survey, the mean share of immigrants, $x$, is about $6.87 \%$, and the mean annual wage of native workers is around 18,365 euros, whereas the mean hourly wage is about 9.67 euros.

The figures in Appendix 1 provide some information about the incidence of immigration and the labor market outcomes of native workers. The increase in the proportion of immigrants in the labor force has been the highest in the loweducation and low-potential work experience groups (Figs. 4 and 7). The natives' employment rates and annual and hourly wages are increasing in potential work experience and educational levels and are higher for men than for women (Figs. 5, 8 and 9). Similarly, we also illustrate the supply shocks experienced by the groups defined in terms of sector of activity. Specifically, given the large number of cells, we have plotted the average immigrant supply shock and the natives' employment

\footnotetext{
${ }^{12}$ As mentioned above, when we use work permits data, this variable is constructed using the information provided by the Labor Force Survey (LFS). Notice that as the population cannot be defined by sector, the denominator, $p_{i t}$, does not have sectoral variation, so that the employment rate of a group defined by age and gender in each year of the sample can just be recovered by simply adding $e_{i t}$ across sectors.

${ }^{13}$ Given that the number of cells we are using is rather high, the LFS estimates of employment and population may not be as accurate as, for instance, the data from the Census of Population. As a result, in some cells, the employment of native born workers is underestimated.
} 
Table 1 Summary statistics

\begin{tabular}{|c|c|c|c|c|c|}
\hline Variable & Observations & Mean & $\begin{array}{l}\text { Standard } \\
\text { deviation }\end{array}$ & Minimum & Maximum \\
\hline \multicolumn{6}{|c|}{ Employment rates } \\
\hline \multicolumn{6}{|c|}{ Sample I: Census data (all immigrants) } \\
\hline$x$ & 128 & 0.0567 & 0.0737 & 0.0030 & 0.3827 \\
\hline$e$ & 128 & 0.5864 & 0.2577 & 0.0823 & 0.9579 \\
\hline \multicolumn{6}{|c|}{ Sample II: Register of work permits (legal immigrants) } \\
\hline$x$ & 2,395 & 0.0089 & 0.02852 & 0 & 0.5235 \\
\hline$e$ & 2,395 & 0.5196 & 0.2147 & 0.1677 & 0.8712 \\
\hline \multicolumn{6}{|l|}{ Wages } \\
\hline \multicolumn{6}{|c|}{ Sample III: Wage structure survey (legal immigrants) } \\
\hline$x$ & 64 & 0.0686 & 0.0797 & 0 & 0.3317 \\
\hline aw & 64 & 18,365 & 10,127 & 4,530 & 45,621 \\
\hline hw & 64 & 9.6722 & 4.8057 & 4.4784 & 22.6598 \\
\hline
\end{tabular}

Cells are defined by labor market experience, gender and education when using data from the Census of Population and the Wage Structure Survey, and by age, gender and sector of activity when using data from the work permits register. The initial number of cells in the sample of work permits is 2,464 , but we have eliminated 69 cells in which the LFS does not provide information about the employment rates of natives.

rate for the period considered in each sector of activity by age for men and women separately. ${ }^{14}$ As can be observed (Fig. 6), there is some deal of variation across sectors both for men and women. ${ }^{15}$ In both cases, the immigration supply shock is larger for the three younger age cohorts.

\section{Empirical approach}

To estimate the effect of the immigration rates, $x$, on the native labor market outcomes, we perform the following regressions:

$$
\begin{gathered}
\log \left(\frac{e_{i t}}{1-e_{i t}}\right)=\beta x_{i t}+\delta_{i t}+\varepsilon_{i t}, \\
\log w_{i t}=\beta x_{i t}+\delta_{i t}+\varepsilon_{i t},
\end{gathered}
$$

\footnotetext{
${ }^{14}$ As the number of cells we are considering is somehow large $(4 \times 2 \times 44 \times 7 \quad 2,464$ cells $)$, we prefer to report the data in this fashion rather than separately for each year.

${ }^{15}$ In the figures, we exclude sector 44 (domestic care) where the incidence of immigration is much higher than in the rest.
} 
where the dependent variable in Eq. 1 is the employment rate of native workers and in Eq. 2 is, alternatively, the mean annual and hourly wages of native workers. ${ }^{16}$ These specifications include a vector of fixed effects, $\delta$, reflecting the dimensions along which cells are defined. The vector of fixed effects also contains interactions between the several dimensions along which cells have been defined. Specifically, for the sample of work permits, we have included interactions between sector and year, age and year and sector and age, whereas for the census and wage data, the interactions are between education and year, experience and year and education and experience. The first two groups of interactions control for the possibility that the impact of sector, education, experience and age changed over time, and the last one controls for the fact that the experience and age profiles have a different effect across schooling and sector groups, respectively.

We report both the estimates of the coefficient $\beta$ and the corresponding elasticity. For this, as in Borjas (2003), we define an alternative measure of the immigration shock, $x_{i t}^{\prime}=m_{i t} / n_{i t}$, so that the corresponding elasticity of the employment rate with respect to the ratio of immigrants to native workers is

$$
\left(\frac{\partial e_{i t}}{\partial x_{i t}^{\prime}}\right)\left(\frac{x_{i t}^{\prime}}{e_{i t}}\right)=\frac{1}{\left(1+x_{i t}^{\prime}\right)^{2}}\left(\frac{\partial e_{i t}}{\partial x_{i t}}\right)\left(\frac{x_{i t}^{\prime}}{e_{i t}}\right),
$$

where

$$
\left(\frac{\partial e_{i t}}{\partial x_{i t}}\right)=\beta \frac{\exp \left(\beta x_{i t}+\delta_{i}\right)}{\left[1+\exp \left(\beta x_{i t}+\delta_{i}\right)\right]^{2}}
$$

is the marginal effect. Similar expressions are obtained for the wage equations. We evaluate these magnitudes at each observation and then calculate the mean.

Under the assumption of no selection bias (that is, no correlation between the fixed effects and the variable $x$ ), consistent estimates of the parameter of interest, $\beta$, in Eqs. 1 and 2 can be obtained by ordinary least squares (OLS). Nevertheless, if we think that selectivity effects are present, the fixed effects can be treated as additional parameters to be estimated, which therefore allows for correlation between them and the explanatory variable $x$. If we assume that no selection bias is present after controlling for fixed effects, then consistent estimates of the parameters can be obtained by OLS regression on the fixed effects model. On the other hand, insofar as native workers, immigrants or other factors of production move across sectors or regions depending on employment demand conditions, selectivity effects are likely to be present in the specification in which cells are defined using either sectors or regions. In this case, we use an instrumental variables (IV) strategy to obtain the true causal effect of $x$ on the dependent variable. Ideally, we would like to use an instrument based on information about the labor market behaviour of the immigrants in their country of origin (like in Friedberg 2001). Unfortunately, we do not have that type of information. Instead, our instrument comes from observation of the administrative procedure for

\footnotetext{
${ }^{16}$ In the case of the employment regression, as the dependent variable is within the $(0,1)$ interval, we impose a logistic transformation. Nonetheless, results from linear regressions are similar to those reported in the text.
} 
awarding work permits. We regress the probability of a work permit being awarded on immigrant characteristics and some indicators of the labor demand conditions in each particular cell of the labor market and recover the residual as an instrument of the immigration shock. This residual ought to capture only the discretionary and random elements introduced by the administrative procedure, not labor demand conditions. ${ }^{17}$

\section{Results}

In this section, we report the estimates from the different models described in Section 4. Two sets of estimates are presented. The first one refers to the effect of immigrant shock on natives' employment rates. The second set of results examines the effect of immigrant shock on natives' wages. ${ }^{18}$ We report the results from pooled data estimation without and with fixed effects; and from separate estimations by gender.

\subsection{Immigration and employment rates of natives}

We first present the results from estimations relying on cells being defined by gender, educational level and potential work experience. The data are from the Census of Population for 1991 and 2001. There are pros and cons in using this sample. First, in principle, the census should provide a good measure of the total immigration to Spain, both legal and illegal, including immigrants from other EU countries. Moreover, as cells are defined along the gender, education and experience dimensions, there are no reasons to expect that the mobility across cells is an issue for the estimation. On the minus side, the number of cells used in the estimation (64 per year) is significantly lower than the number of cells that could be considered when using other dimensions.

Overall, we do not find statistically significant effects of the immigration shock on the employment rates of native-born workers in any specification (see Table 2). When interactions of the fixed effects are included as additional regressors, the impact of immigration on the employment rate is negative. In particular, the estimated elasticity at the aggregate level is around -0.022 , so that an increase of $10 \%$ in the ratio of immigrants to native workers would decrease the employment rate of native workers by $0.22 \%$. Separate estimations by gender show that the impact of immigration on the employment rate turns out to be positive, although not statistically significant at standard levels, and smaller for men than for women. ${ }^{19}$

\footnotetext{
${ }^{17}$ As shown below, regional mobility does not seem to introduce much of a bias in the estimation of the impact of migration of labor market outcomes of natives. However, using sectors in the definition of cells leads to a significant difference between OLS and IV estimates.

${ }^{18}$ Additionally, we have also estimated the effect of immigrants on natives' unemployment rates. Results are qualitatively similar, with the opposite sign, to those obtained for employment rates. They are available upon request.

${ }^{19}$ As $x_{i t}$ gives the immigrant share among labor force participants in each cell, one could think that the labor force participation decision may introduce some endogeneity in this variable. This problem can be addressed using an instrument. Following Borjas (2003), we use the proportion of immigrants in the total population as an instrument. The idea is that this variable is correlated with $x_{i t}$ but not with our dependent variable. The IV estimation yields estimates of the coefficients and significance levels very similar to those obtained without instrumenting participation.
} 
Table 2 OLS estimates using education gender experience groups

\begin{tabular}{|c|c|c|c|c|c|c|c|}
\hline & $\begin{array}{l}\text { Coefficient } \\
\beta\end{array}$ & $\begin{array}{l}\text { Standard } \\
\text { error }\end{array}$ & $\begin{array}{l}\text { Marginal } \\
\text { effects }^{\mathrm{a}}\end{array}$ & Elasticity $^{\mathrm{a}}$ & $\begin{array}{l}\text { Fixed } \\
\text { effects }\end{array}$ & Interactions & $\begin{array}{l}\text { No. of } \\
\text { observations }\end{array}$ \\
\hline \multicolumn{8}{|l|}{ All } \\
\hline 1 & 0.3276 & 1.6733 & 0.0754 & 0.0089 & No & No & 128 \\
\hline 2 & 1.5432 & 1.8734 & 0.2818 & 0.0336 & Yes & No & 128 \\
\hline 3 & 1.0357 & 2.3738 & 0.1892 & 0.0219 & Yes & Yes & 128 \\
\hline \multicolumn{8}{|l|}{ Men } \\
\hline 4 & 1.5982 & 1.2027 & 0.2569 & 0.0225 & No & No & 64 \\
\hline 5 & 1.1691 & 1.0392 & 0.1760 & 0.0169 & Yes & No & 64 \\
\hline 6 & 0.9662 & 1.8957 & 0.1499 & 0.0144 & Yes & Yes & 64 \\
\hline \multicolumn{8}{|c|}{ Women } \\
\hline 7 & 4.2688 & 2.1347 & 1.0328 & 0.1603 & No & No & 64 \\
\hline 8 & 0.9683 & 1.0504 & 0.1947 & 0.0299 & Yes & No & 64 \\
\hline 9 & 2.2576 & 4.4023 & 0.4463 & 0.0671 & Yes & Yes & 64 \\
\hline
\end{tabular}

Sample I: Census data. Dependent variable: $\log (e /(1+e))$. Regression models in rows 3, 6 and 9 include interactions between education and experience fixed effects, education and period fixed effects and experience and period fixed effects. Standard errors are clustered by cells to adjust for possible serial correlation. All the regressions are weighted by the sample size used to calculate the dependent variable.

${ }^{a}$ Mean values

In Table 3, we present similar estimates from the same sample augmented by also exploiting the variability across the 17 Spanish regions. As noted above, the mobility across regions could yield unreliable estimates of the impact of immigration on the employment rate when using cross-region correlations. We obtain elasticities of a similar order of magnitude to those obtained without exploiting the regional variation, only that they are more precisely estimated. This result is not particularly surprising given the low inter-regional labor mobility of natives.

Table 3 OLS estimates using education gender experience regions groups

\begin{tabular}{|c|c|c|c|c|c|c|c|}
\hline & $\begin{array}{l}\text { Coefficient } \\
\beta\end{array}$ & $\begin{array}{l}\text { Standard } \\
\text { error }\end{array}$ & $\begin{array}{l}\text { Marginal } \\
\text { effects }^{\mathrm{a}}\end{array}$ & Elasticity $^{\mathrm{a}}$ & $\begin{array}{l}\text { Fixed } \\
\text { effects }\end{array}$ & Interactions & $\begin{array}{l}\text { No. of } \\
\text { observations }\end{array}$ \\
\hline 1 & 1.4793 & 0.6329 & 0.3365 & 0.0340 & No & No & 2,167 \\
\hline 2 & 1.0752 & 0.3447 & 0.1954 & 0.0215 & Yes & No & 2,167 \\
\hline 3 & 2.4418 & 0.4196 & 0.4428 & 0.0479 & Yes & $\begin{array}{l}\text { Region } \times \text { year; } \\
\text { education } \times \text { year; } \\
\text { experience } \times \text { year }\end{array}$ & 2,167 \\
\hline 4 & 0.9381 & 0.3566 & 0.1704 & 0.0179 & Yes & $\begin{array}{l}\text { Region } \times \text { year; education } \times \\
\text { year; experience } \times \text { year; } \\
\text { education } \times \text { experience }\end{array}$ & 2,167 \\
\hline
\end{tabular}

Sample I: Census data. Dependent variable: $\log \left(e /\left(\begin{array}{ll}1 & e\end{array}\right)\right)$. Standard errors are clustered by cells to adjust for possible serial correlation. All the regressions are weighted by the sample size used to calculate the dependent variable.

${ }^{\text {a }}$ Mean values 


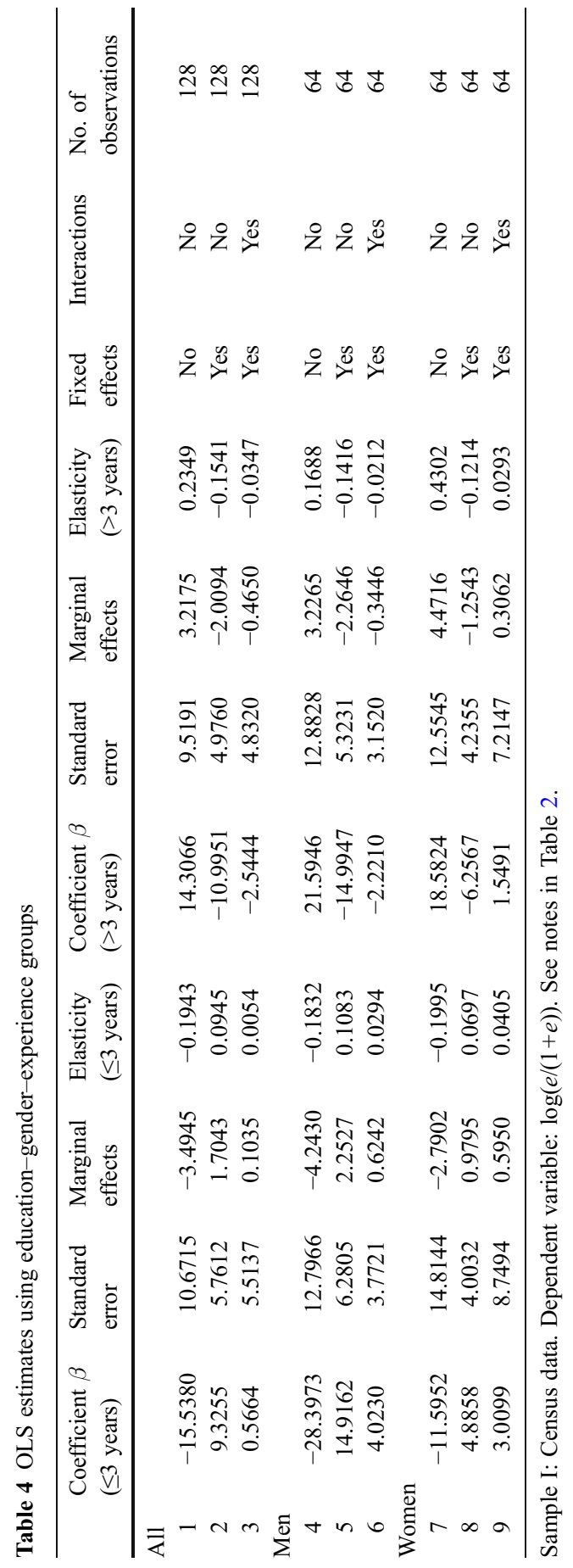


It is plausible that the impact of immigration on labor market outcomes changes with the assimilation process of immigrants. As Cohen-Goldner and Paserman (2004) pointed out, "there are reasons to believe that the effect of a given immigration wave is not uniform over time." If immigrants were relatively close substitutes of native workers when they arrive in the host country, we would expect to see an immediate impact on the natives' labor market outcomes. However, as time goes by and capital and labor adjust to immigration, the medium- and long-run responses could be smaller. On the contrary, if immigrants, at the time of their arrival, are poor substitutes of native workers, as their human capital is not fully transferable to the host country, the immediate impact of immigration on natives' labor market outcomes would be negligible. Nevertheless, as they acquire local labor market skills, they could compete with native workers, so that the mediumand long-run effects on the natives' outcomes might be substantial. Trying to disentangle these effects, we have separated immigrants in two groups: immigrants with less than 3 years of residence in Spain and immigrants with more than 3 years of residence in Spain. Table 4 reports estimates for these two groups separately. When including the interactions between the fixed effects, the estimated elasticities are low and statistically non-significant, but slightly more negative with regards to immigrants with more than 3 years of residence.

We now turn to the results obtained with Sample II constructed from the data from the administrative register of work permits for the 1993-1999 period. This data set does not provide information on the immigrant's education level, so that we have to define the cells along the sectoral dimension. Results in Table 5 show that when including fixed effects and interactions among them in the specification, the estimated OLS coefficient is negative and statistically significant. In particular, the estimated elasticity is -0.18 , so that an increase of $10 \%$ in the ratio of immigrant to native workers would decrease the employment rate of native-born workers by $1.8 \%$. The estimates for men and women separately yield smaller elasticities in absolute values than the ones obtained at the aggregate level $(-0.035$ for men and -0.088 for women), but the estimated coefficients are still statistically significant at the standard levels.

As we only observe legal immigrants in this sample, results in Table 5 could be read as logically saying that legal immigrants are more "substitute" with respect to native workers. For the reasons already noted, this conclusion would be misleading. In this case, given the likely sectoral mobility of immigrants and natives, OLS estimates are likely to be biased. To correct this bias, we perform an IV estimation using as instrument the residual of a regression of the probability of a work permit being awarded on immigrant characteristics and some indicators of the labor demand conditions in each particular cell of the labor market. The correlation coefficient between this instrument and the immigration variable, $x$, is 0.0238 ( $p$ value $=0.34),{ }^{20}$ and the first-stage $F$ test is $2.8 .{ }^{21}$ The proportion of work permits requested that are finally awarded is about $88 \%$. The sectors in which the number of work permits requested is higher are domestic care, agriculture, hotels and restaurants and construction.

\footnotetext{
${ }^{20}$ In Appendix 2, we present the results from the probit estimation of the approval rate of work permits.

${ }^{21}$ Notice that the IV results may suffer from small sample bias, given that the $F$ test is below 5 (see Staiger and Stock 1997). Therefore, these results should be interpreted with caution.
} 
Table 5 OLS estimates using age gender sector groups

\begin{tabular}{|c|c|c|c|c|c|c|c|}
\hline & Coefficient $\beta$ & $\begin{array}{l}\text { Standard } \\
\text { error }\end{array}$ & $\begin{array}{l}\text { Marginal } \\
\text { effects }^{\mathrm{a}}\end{array}$ & Elasticity $^{\mathrm{a}}$ & $\begin{array}{l}\text { Fixed } \\
\text { effects }\end{array}$ & Interactions & $\begin{array}{l}\text { No. of } \\
\text { observations }\end{array}$ \\
\hline \multicolumn{8}{|l|}{ All } \\
\hline 1 & 0.1125 & 2.3744 & 0.0005 & 0.0057 & No & No & 2,395 \\
\hline 2 & 9.7442 & 1.6585 & 0.1071 & 0.1364 & Yes & No & 2,395 \\
\hline 3 & 15.0422 & 2.3176 & 0.1687 & 0.1823 & Yes & Yes & 2,395 \\
\hline \multicolumn{8}{|c|}{ Men } \\
\hline 4 & 3.4443 & 0.9333 & 0.0268 & 0.1261 & No & No & 1,231 \\
\hline 5 & 3.8672 & 1.0398 & 0.0577 & 0.0451 & Yes & No & 1,231 \\
\hline 6 & 3.6505 & 1.2259 & 0.0551 & 0.0349 & Yes & Yes & 1,231 \\
\hline \multicolumn{8}{|c|}{ Women } \\
\hline 7 & 8.9504 & 5.5090 & 0.0208 & 0.4765 & No & No & 1,164 \\
\hline 8 & 12.9204 & 3.2577 & 0.1033 & 0.0995 & Yes & No & 1,164 \\
\hline 9 & 13.1792 & 4.9524 & 0.1060 & 0.0882 & Yes & Yes & 1,164 \\
\hline
\end{tabular}

Sample II: Work permits. Dependent variable: $\log (e(1+e))$. Regression models in rows 3, 6 and 9 include interactions between sector and age fixed effects, age and period fixed effects and sector and period fixed effects. Standard errors are clustered by cells to adjust for possible serial correlation. All the regressions are weighted by the sample size used to calculate the dependent variable.

${ }^{a}$ Mean values

The two-stage least squares estimates of the parameter $\beta$, presented in Table 6 , are positive but not statistically significant, so that we cannot reject the hypothesis that immigration has no impact on natives' employment rates. The contrast between the OLS and IV estimates indicates that the distribution of immigrants across sectors is not independent of employment conditions in those sectors. In fact, conventional wisdom is that immigrants cluster in those activities where the native labor force is more reluctant to work. As a result, OLS yields an

Table 6 IV estimates using age gender sector groups

\begin{tabular}{|c|c|c|c|c|c|c|c|}
\hline & Coefficient $\beta$ & $\begin{array}{l}\text { Standard } \\
\text { error }\end{array}$ & $\begin{array}{l}\text { Marginal } \\
\text { effects }^{\mathrm{a}}\end{array}$ & Elasticity $^{\mathrm{a}}$ & $\begin{array}{l}\text { Fixed } \\
\text { effects }\end{array}$ & Interactions & $\begin{array}{l}\text { No. of } \\
\text { observations }\end{array}$ \\
\hline \multicolumn{8}{|l|}{ All } \\
\hline 1 & 0.3040 & 0.4216 & 0.00005 & 0.0066 & No & No & 1,714 \\
\hline 2 & 0.2137 & 0.3416 & 0.00004 & 0.0028 & Yes & No & 1,714 \\
\hline 3 & 0.7739 & 0.6281 & 0.00016 & 0.0074 & Yes & Yes & 1,714 \\
\hline \multicolumn{8}{|c|}{ Men } \\
\hline 4 & 0.6719 & 1.4206 & 0.0005 & 0.0844 & No & No & 950 \\
\hline 5 & 0.0549 & 1.8457 & 0.00006 & 0.0001 & Yes & No & 950 \\
\hline 6 & 0.4434 & 2.9701 & 0.00006 & 0.0011 & Yes & Yes & 950 \\
\hline \multicolumn{8}{|c|}{ Women } \\
\hline 7 & 0.1379 & 0.3969 & 0.00003 & 0.0002 & No & No & 764 \\
\hline 8 & 0.3298 & 0.1497 & 0.00005 & 0.0040 & Yes & No & 764 \\
\hline 9 & 0.9247 & 1.3402 & 0.00009 & 0.0040 & Yes & Yes & 764 \\
\hline
\end{tabular}

Sample II: Work permits. Dependent variable: $\log (e(1+e))$. See notes in Table 5 . 
Table 7 OLS estimates using education gender experience groups

\begin{tabular}{ccccccc}
\hline \multicolumn{2}{c}{ Coefficient $\beta$} & $\begin{array}{l}\text { Standard } \\
\text { error }\end{array}$ & Elasticity $^{\text {a }}$ & $\begin{array}{l}\text { Fixed } \\
\text { effects }\end{array}$ & Interactions & $\begin{array}{l}\text { No. of } \\
\text { observations }\end{array}$ \\
\hline \multicolumn{2}{l}{ Annual wage } \\
1 & 3.6420 & 1.3922 & 0.0222 & No & No & 64 \\
2 & 0.4174 & 0.6364 & 0.0025 & Yes & No & 64 \\
3 & 1.2102 & 1.5738 & 0.0074 & Yes & Yes & 64 \\
\multicolumn{2}{l}{ Hourly wage } & & & & & 64 \\
4 & 3.6004 & 1.2298 & 0.1079 & No & No & 64 \\
5 & 0.0590 & 0.5475 & 0.0018 & Yes & No & 64 \\
6 & 0.7237 & 1.1382 & 0.0217 & Yes & Yes & 64 \\
\hline
\end{tabular}

Sample III: Wage structure survey. Dependent variable: $\log w$. Regression models in rows 3 and 6 include interactions between education and experience fixed effects.

${ }^{\text {a }}$ Mean values

overestimation of the immigration's negative impact on the natives' employment rates. The difference between the OLS and IV results implies that the negative correlation between immigration and native employment found by OLS is not entirely due to an adverse impact of immigration, but rather to the immigrants having entered to those sectors where the employment rate of native-born workers is lower. These results are qualitatively similar to the ones obtained by Friedberg (2001), who uses supply shock by occupation to identify the labor market impact of immigration in the Israeli labor market.

\subsection{Immigration and wages}

For the estimation of the impact of immigration on natives' annual and hourly wages, we use the data from the Wage Survey Structure for 2002, which covers manufacturing, construction and services sectors. On the one hand, the survey allows us to define cells along the gender, education and experience dimensions and provides a good measure of legal immigration to Spain as well as a relevant measure of Spanish workers' wages. On the other hand, the primary sector and domestic services, two sectors with an important presence of immigrants, are not covered by the survey. Moreover, it is only possible to observe the incidence of legal immigrants in its last wave, referred to 2002, so that the number of cells used in the estimation (64) is low. ${ }^{22}$

Table 7 presents the estimates. The results point to the inexistence of any sizeable effect of immigration on the wages of native workers. This could be possibly explained by the existence of minimum wages (fixed by sectoral collective agreements) that prevents wages in the formal sector to decrease in response to immigration. As done in the case of employment rates, we also exploit the geographical variability for wage data. When using the geographical variation, the sample size being noticeably larger, the estimated elasticities (see Table 8) are ${ }^{22}$ Given the low number of cells in this case, we do not perform separate estimates for men and
women. 
negative and become statistically significant. However, their absolute values remain very low: In most specifications, an increase in the proportion of immigrants of $10 \%$ would lower wages by less than $0.2 \%$.

\section{Conclusions}

The economic analysis of immigration has devoted much attention to the identification of its impact on the labor market outcomes of native-born workers. However, the empirical evidence on this matter is not totally conclusive and, to a large extent, refers to the US case, where relative wages adjust to the relative supply and demand of workers of different characteristics to a larger extent than in the "rigid" European labor markets.

In this paper, we have searched for some effects of immigration on the Spanish labor market. During the period 1993-1999, the number of foreign workers with work permits increased by about $70 \%$, and the proportion of immigrants in the total population increased by more than $8 \%$ age points between 1991 and 2005 . This strong rise has spurred some concerns about a possible fall in the labor market performance of native-born workers. We have searched for the effects of immigration on employment and wages of native workers using three different samples varying in coverage of legal and illegal immigration and in the dimensions along which labor market segments can be constructed.

Overall, we do not find any significant negative effect of immigration on either the employment rates or the wages of native workers. Using census data, which supposedly include both legal and illegal immigrants, the elasticity of the employment rate with respect to the proportion of immigrants is around -0.02 . In a sample covering only legal immigrants with work permits, the estimated elasticity by OLS is -0.1 . However, as this estimation relies on the sectoral variation of the incidence of immigration and employment rates, there are strong reasons to believe that OLS provides a biased estimation of the causal effect of immigration on employment rates in this case. When using an IV procedure, we cannot reject the

Table 8 OLS estimates using education gender experience region groups

\begin{tabular}{|c|c|c|c|c|c|c|}
\hline & Coefficient $\beta$ & $\begin{array}{l}\text { Standard } \\
\text { error }\end{array}$ & Elasticity & $\begin{array}{l}\text { Fixed } \\
\text { effects }\end{array}$ & Interactions & $\begin{array}{l}\text { No. of } \\
\text { observations }\end{array}$ \\
\hline \multicolumn{7}{|c|}{ Annual wage } \\
\hline 1 & 1.1703 & 0.2750 & 0.0047 & No & No & 1,053 \\
\hline 2 & 0.1382 & 0.1043 & 0.0006 & Yes & No & 1,053 \\
\hline 3 & 0.2017 & 0.1053 & 0.0008 & Yes & Yes & 1,053 \\
\hline \multicolumn{7}{|c|}{ Hourly wage } \\
\hline 4 & 1.2630 & 0.2435 & 0.0246 & No & No & 1,053 \\
\hline 5 & 0.1088 & 0.0904 & 0.0021 & Yes & No & 1,053 \\
\hline 6 & 0.1640 & 0.0869 & 0.0032 & Yes & Yes & 1,053 \\
\hline
\end{tabular}

Sample III: Wage structure survey. Dependent variable: $\log w$. See notes in Table 7. We have dropped 35 cases, out of 1,088 observations, in which the annual and hourly wages of native workers were missing. 
hypothesis that the estimated elasticity is zero. As for the elasticity of natives' wages to immigration, we also failed to find any significant effect of legal immigration.

This result has some interesting policy implications for the debate about the effects of an amnesty for illegal immigrants. Such a measure, which covered about 700,000 illegal immigrants, was implemented during the first half of 2005 in Spain and resulted in a rise in the proportion of legal immigrants of about $40 \%$. Even taking the most negative of our estimates $(-0.02)$, and assuming that all immigrants being granted work permits were not working before, the amnesty would have resulted in a fall of the employment rate of native-born workers of about $0.8 \%$, which, at the current employment rate of $62 \%$, amounts to less than one half of a percentage point.

Acknowledgment We are grateful to Juan J. Dolado, Juan C. Berganza, Cordelia Reimers, three anonymous referees and the participants at the 2003 Fundación Ramón Areces Conference, 2005 SOLE/EALE Conference, 2006 CREAM Conference and at a FEDEA seminar for helpful comments and suggestions. All remaining errors are our own. We acknowledge the research funding from Fundación BBVA.

\section{Appendix 1}
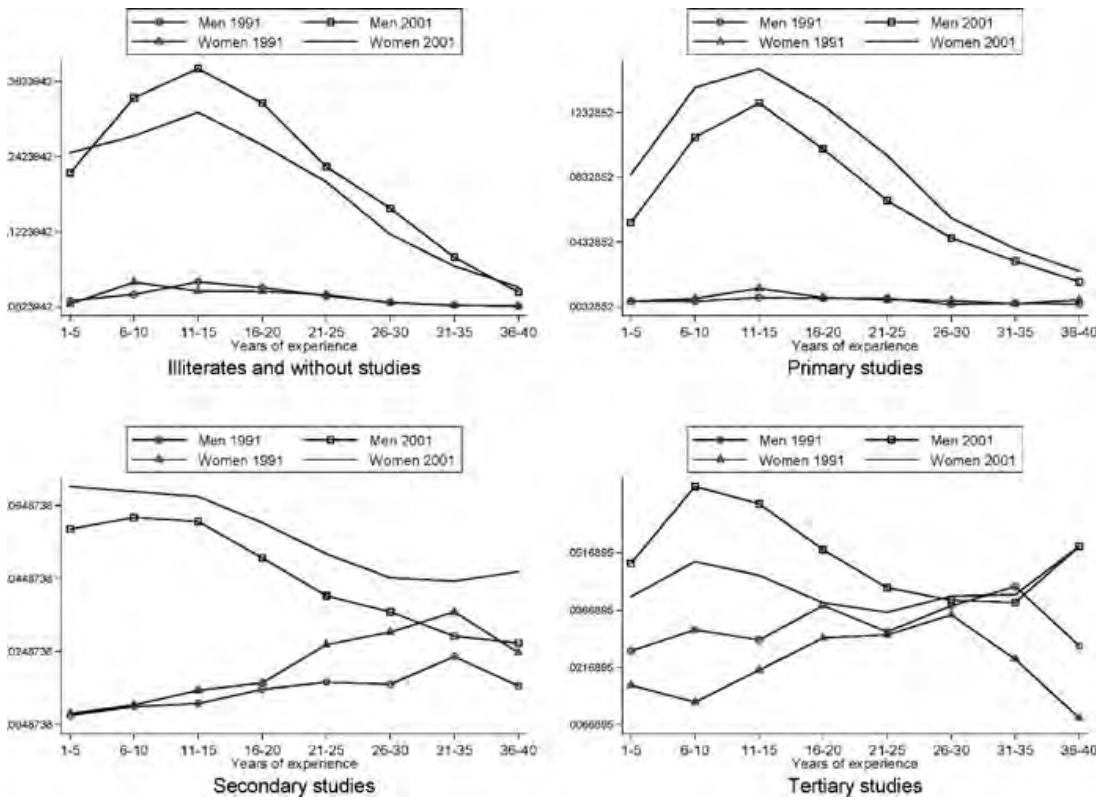

Fig. 4 Incidence of immigration by educational level and years of experience. Source: Census of Population, 1991 and 2001 

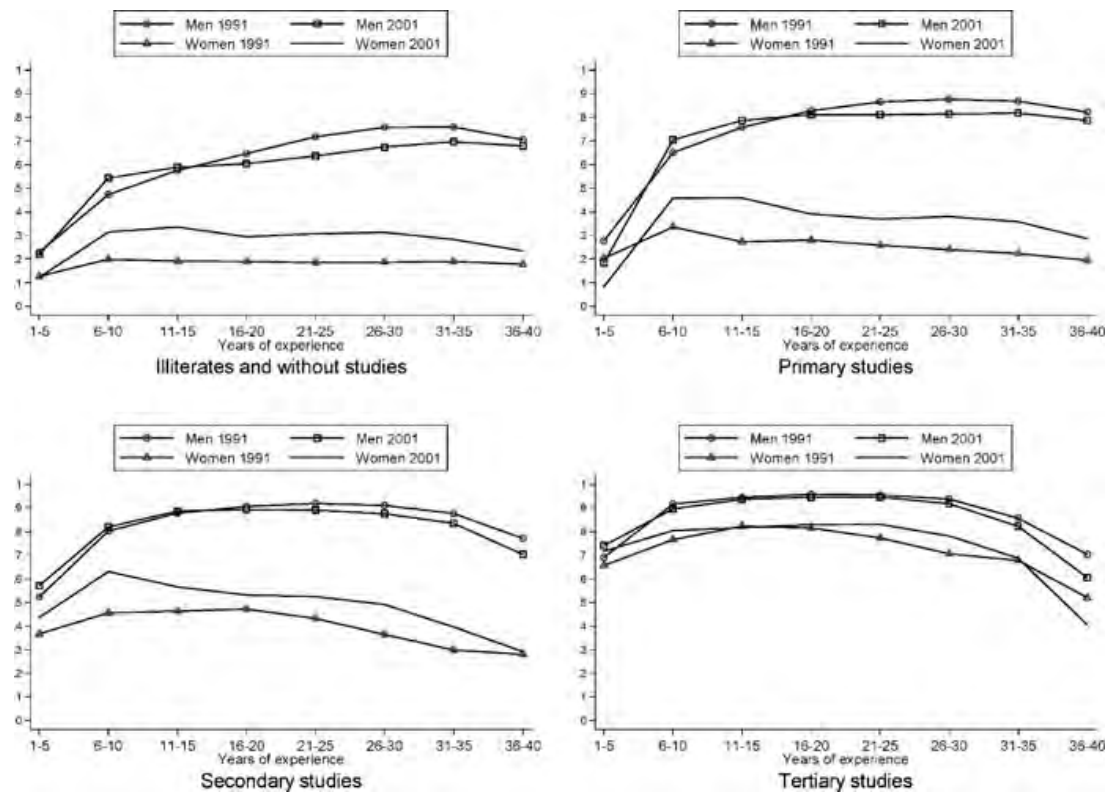

Fig. 5 Employment rates of native workers by educational level and years of experience. Source: Census of Population, 1991 and 2001
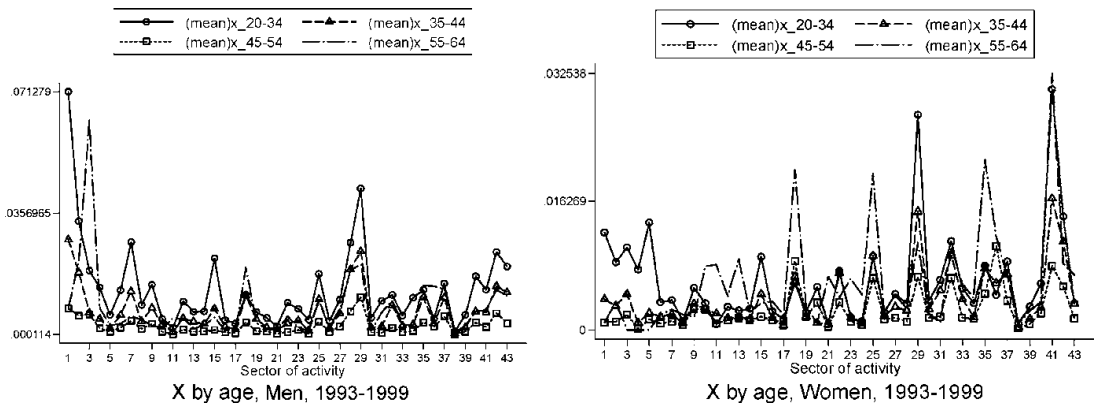

Fig. 6 Incidence of legal immigration by age and sector of activity. Source: Register of Work Permits, 19931999 

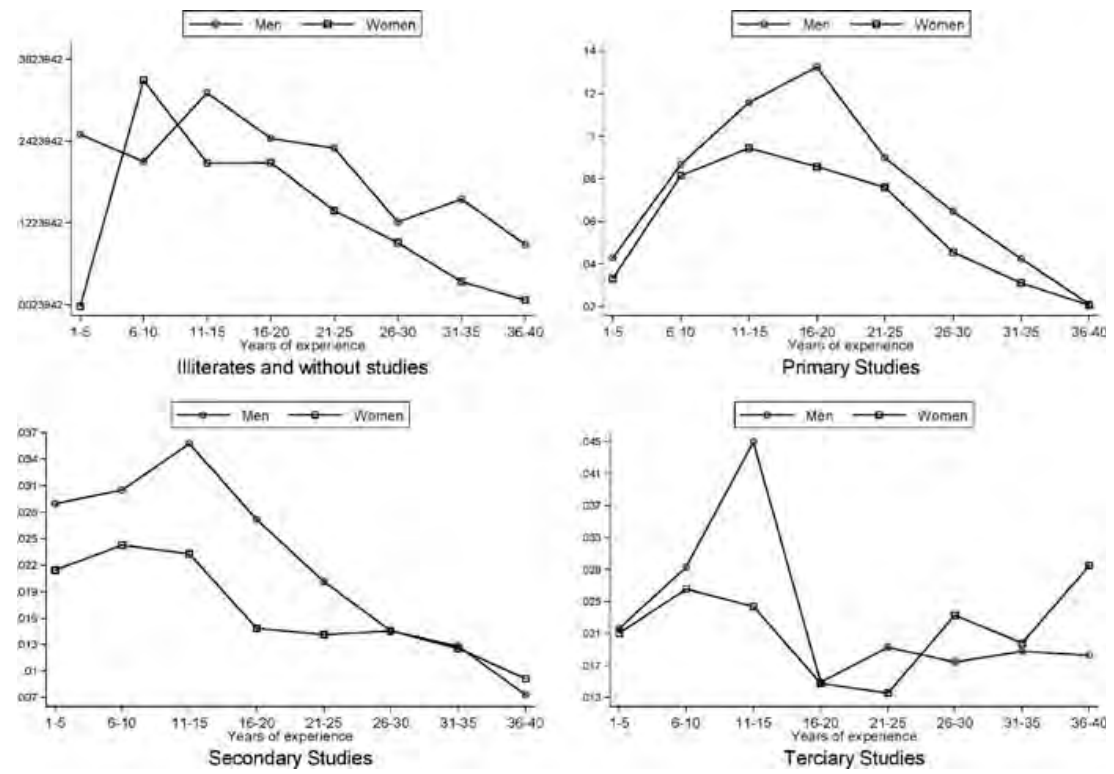

Fig. 7 Incidence of immigration by educational level and years of experience. Source: Wage Structure Survey, 2002
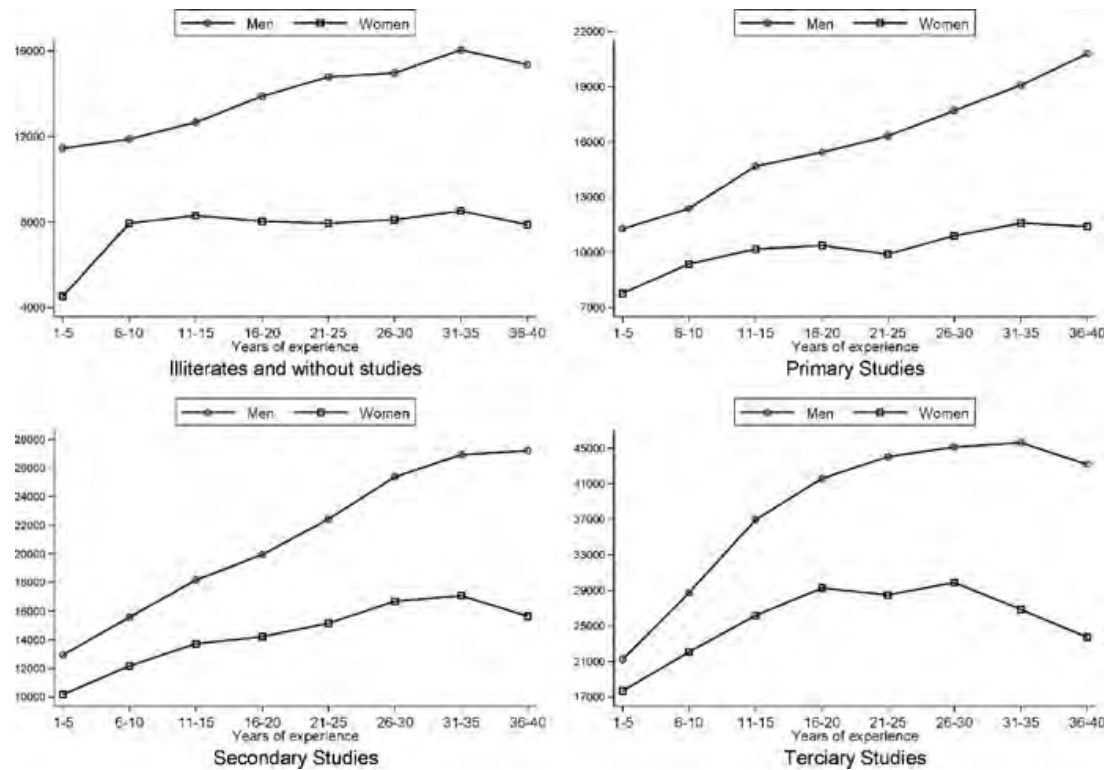

Fig. 8 Annual wages of native workers by educational level and years of experience. Source: Wage Structure Survey, 2002 

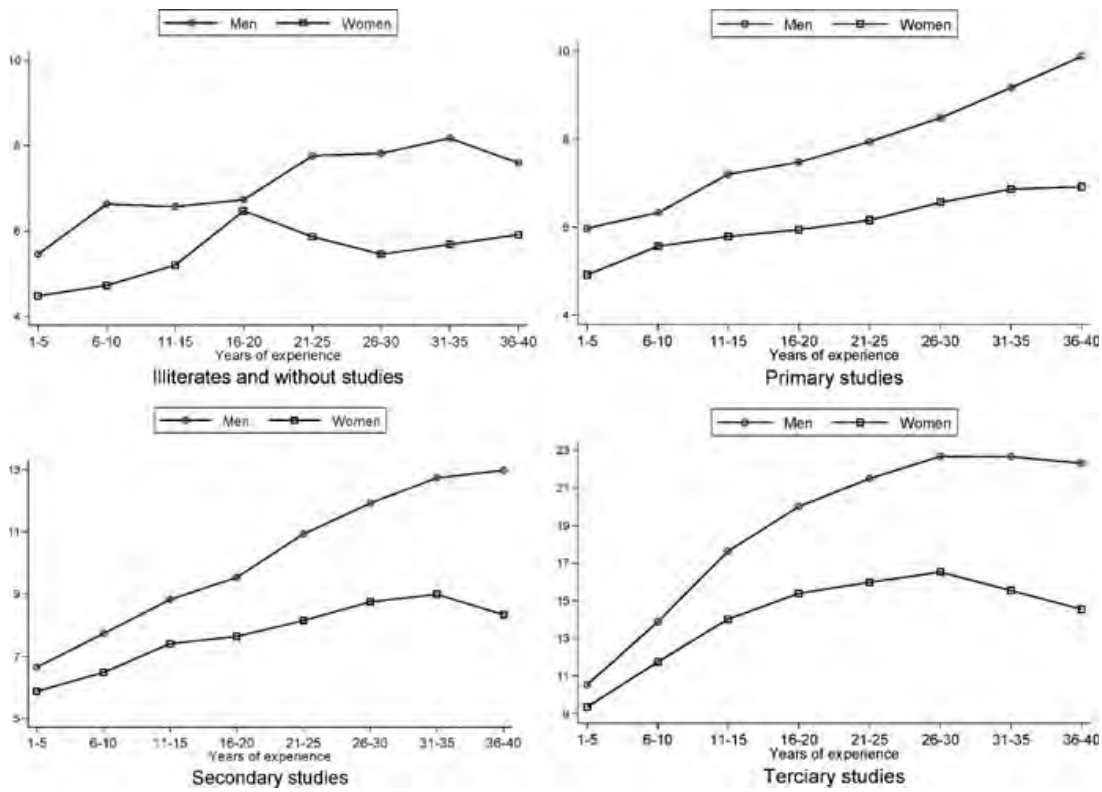

Fig. 9 Hourly wages of native workers by educational level and years of experience. Source: Wage Structure Survey, 2002

\section{Appendix 2}

Table 9 Dependent variable: probability of awarding a work permit

\begin{tabular}{ccc}
\hline Variable & Coefficient & Standard error \\
\hline Age & 0.0662 & 0.0017 \\
Age $^{2}$ & 0.0006 & 0.00002 \\
Sex & 0.0511 & 0.0050 \\
Crec 9394 & 0.00030 & 0.0001 \\
Crec 9495 & 0.0009 & 0.0001 \\
Crec 9596 & 0.0011 & 0.0001 \\
Crec 9697 & 0.0026 & 0.0001 \\
Crec 9798 & 0.0048 & 0.0002 \\
Constant & 0.2817 & 0.0301 \\
Log likelihood & 194,733 & \\
No. of observations & 521,355 &
\end{tabular}

The variables Crec 9394 to Crec 9798 are defined as the employment growth rate by sector and region between two consecutive years, $t$ and $t \quad 1$, for those individuals observed in period $t$ and take the value zero otherwise. 


\section{References}

Amuedo Dorantes C, De la Rica S (2005) Immigrants' responsiveness to labor market conditions and its implications on regional disparities: evidence from Spain IZA Discussion Paper No. 1557

Angrist J, Kugler A (2003) Productive or counter productive: labour market institutions and the effect of immigration on EU natives. Econ J 113(488):302 331

Boeri T, Bertola G, Brücker H, Coricelli F, Dolado JJ, Fitzgerald J, de la Fuente A, Garibaldi P, Hanson G, Jimeno JF, Portes R, Saint Paul G, Spilimbergo A (2002) Who is afraid of the big enlargement? CEPR Policy Paper No. 7

Borjas G (1994) The economics of immigration. J Econ Lit 32(4):1667 1717

Borjas G (1999) The economic analysis of immigration. In: Ashenfelter O, Card D (eds) Handbook of labour economics, vol. 3A. North Holland

Borjas G (2003) The labor demand curve is downward sloping: reexamining the impact of immigration on the labor market. Q J Econ 118(4):1335 1378

Card D (1990) The impact of the Mariel boatlift on the Miami labor market. Ind Labor Relat Rev 43(2):245 257

Card D (2001) Immigrants inflows, native outflows, and the local 1abour market impacts of higher immigration. J Labor Econ 19(2):22 64

Card D, DiNardo JE (2001) Do immigrant inflows lead to native outflows? Am Econ Rev 90(2):360 367

Carrasco C (2002) El Impacto Económico de la Inmigración: Incorporación al Mercado de Trabajo Formal e Informal. In: La Inmigración: Una Realidad en España. Seminario de Investigación para la Paz

Carrasco R, Jimeno JF, Ortega AC (2004) The effect of immigration on the employment opportunities of native born workers: some evidence for Spain. FEDEA Working Paper No. 200417

Cohen Goldner S, Paserman MD (2004) The dynamic impact of immigration on natives' labor market outcomes: evidence from Israel. IZA Discussion Paper No. 1315

Collado D, Iturbe Ormaetxe I, Valera G (2004) Quantifying the impact of immigration in the Spanish welfare state. Int Tax Public Financ 11(3):335 353

Coppel J, Dumont JC, Visco I (2001) Trends in immigration and economic consequences. OECD Economics Department Working Papers No. 284

Dolado JJ (2002) Los Nuevos Fenómenos Migratorios: Retos y Políticas”. In: García Milá T (ed) Las nuevas Fronteras de la Política Económica en España, CREI, Universidad Pompeu Fabra and Generalitat de Catalunya

Dolado JJ, Jimeno JF, Duce R (1997) Los Efectos de la Inmigración sobre la Demanda Relativa de Trabajo Cualificado vs. Poco Cualificado: Evidencia para España. Cuad Econ ICE 63:11 30

Friedberg R (2001) The impact of mass migration on the Israeli labor market. Q J Econ 116(4):1373 1408

Friedberg R, Hunt J (1995) The impact of immigration on host country wages, employment and growth. J Econ Perspect 9(2):23 44

Hunt J (1992) The impact of the 1962 repatriates from Algeria on the French labor market. Ind Labor Relat Rev 45(2):556 572

Izquierdo A (2002) Panorama de la Inmigración en España al Alba del Siglo XXI. In: La Inmigración: Una Realidad en España. Seminario de Investigación para la Paz

Pischke S, Velling J (1997) Employment effects of immigration to Germany: an analysis based on local labor markets. Rev Econ Stat 79(4):594 604

Staiger D, Stock JH (1997) Instrumental variable regression with weak instruments. Econometrica 65(3):557 586 